\begin{tabular}{|l|l|l||}
\hline \multicolumn{2}{|c|}{ PublisherInfo } \\
\hline \hline PublisherName & $:$ & BioMed Central \\
\hline \hline PublisherLocation & $:$ & London \\
\hline \hline PublisherImprintName & $:$ & BioMed Central \\
\hline \hline
\end{tabular}

\title{
Zebrafish on drugs
}

\begin{tabular}{|l|l|l||}
\hline \multicolumn{2}{|c||}{ ArticleInfo } \\
\hline \hline ArticleID & $:$ & 3839 \\
\hline \hline ArticleDOI & $:$ & $10.1186 /$ gb-spotlight-20001122-02 \\
\hline \hline ArticleCitationID & $:$ & spotlight-20001122-02 \\
\hline \hline ArticleSequenceNumber & $:$ & 276 \\
\hline \hline ArticleCategory & $:$ & Research news \\
\hline ArticleFirstPage & $:$ & 1 \\
\hline \hline ArticleLastPage & $:$ & 2 \\
\hline \hline & $:$ & RegistrationDate : 2000-11-22 \\
ArticleHistory & $:$ & OnlineDate $: 2000-11-22$ \\
\hline \hline ArticleCopyright & $:$ & BioMed Central Ltd2000 \\
\hline \hline ArticleGrants & $:$ & \\
\hline \hline ArticleContext & $:$ & 130591111 \\
\hline \hline
\end{tabular}




\section{William Wells}

Email: wells@biotext.com

In the November 21 Proceedings of the National Academy of Sciences, Peterson et al. describe a screen for chemicals that can be used to interfere with, and time, developmental events in zebrafish (Proc Natl Acad Sci USA 2000, 97:12965-12969). Zebrafish eggs were arrayed three to a well in 96-well plates, along with one of 1,100 synthetic small molecules. The developing embryos were screened once a day for three days for defects in the central nervous system, the cardiovascular system, pigmentation, or ear development, with one person capable of screening approximately 400 compounds a day. Approximately $2 \%$ of the compounds were generally lethal or caused widespread necrosis, but approximately $1 \%$ of the compounds affected a specific aspect of one system under study. Peterson et al. demonstrated the utility of such probes by adding and washing away a particular chemical at different times, thus determining that a critical stage for ear development occurs between 14 and 26 hours postfertilization. Further insight may come from isolation of the proteins targeted by the chemicals, using procedures such as affinity chromatography.

\section{References}

\section{Proceedings of the National Academy of Sciences, [http://www.pnas.org/]}

2. Target-oriented and diversity-oriented organic synthesis in drug discovery.

3. Chemistry or biology: which comes first after the genome is sequenced? 